\title{
Performance of a Water Ionizing Device That Uses Carbon Nanotube for Treating Particulates and Other Pollutants Found in Drinking Water
}

\author{
Mark Franklin P. Manalang, Wilfredo L. Infante, Al-Shaimah A. Alonto, Ryan John L. De Lara, \\ Noel T. Florencondia
}

\begin{abstract}
The study was undertaken to verify performance of a commercially available water ionizing device that uses carbon nanotube to treat particulates and other pollutants found in drinking water. Two (2) deep well stations belonging to a local water concessionaire known to have quality issues were considered. Water samples were collected and analyzed for physicochemical, bacteriological and organic parameters such as Total Alkalinity, Bicarbonates, Acidity, Free CO2, Chlorine, Total Hardness, Calcium Hardness, $\mathrm{Ca}, \mathrm{Mg}, \mathrm{pH}$, Residual Chlorine, Turbidity, TDS, color, Fe, Mn, Total coliform, HPC count and Dieldrin. The device's performance efficiency in treating the pollutants was calculated. The products' claims were verified thru actual test results. Results indicate that the device is not working as it should. It has very minimal color, $\mathrm{Fe}$ and $\mathrm{Mn}$ removal contrary to the product claims and has zero dieldrin treatment capability. On the brighter side, the device reduced total coliform by an average of $59.67 \%$ although HPC count spiked by an average of $1,210 \%$. The obtained results will be useful in optioneering for future treatment technologies for the water concessionaire or similar waterworks.
\end{abstract}

Keywords: dieldrin, $\mathrm{Fe}$, ion exchange, $\mathrm{Mn}$, water treatment

\section{INTRODUCTION}

$\mathrm{P}$ roviding safe and reliable water is an essential task by water concessionaires. Their role is to treat water and purify raw water and make it suitable for human consumption through the removal and killing of pathogenic organisms and remove the objectionable taste, odor, and other undesirable chemical and physical constituents. Various treatment

Revised Manuscript Received on December 30, 2019.

* Correspondence Author

Mark Franklin P. Manalang., Department of Mechanical Engineering Holy Angel University, Angeles City, Pampanga, Philippines. Email: litzekit@yahoo.com.ph

Wilfredo L. Infante., Department of Mechanical Engineering Holy Angel University, Angeles City, Pampanga, Philippines.Email: wlinfante126@gmail.com

Al-Shaimah A. Alonto., College of Science \& Mathematics, Mindanao State University, Marawi City, Philippines.Email: shai.alonto@gmail.com

Ryan John L. De Lara., Graduate School Department, Nueva Ecija University of Science and Technology, Cabanatuan, Nueva Ecija, Philippines. Email: ryanjohn_delara@yahoo.com

Noel T. Florencondia., Graduate School Department, Nueva Ecija University of Science and Technology, Cabanatuan, Nueva Ecija, Philippines. Email: florencondia61@gmail.com

(C) The Authors. Published by Blue Eyes Intelligence Engineering and Sciences Publication (BEIESP). This is an open access article under the CC BY-NC-ND license (http://creativecommons.org/licenses/by-nc-nd/4.0/) processes are used to take out impurities from raw water and these may be in the form of either physical or chemical and both.

Water concessionaires that use groundwater as their major source may only need simple treatment process such as chlorination to comply with the Philippine National Standards for Drinking Water (PNSDW). However, for those with sources whom exhibit presence of contaminants, other treatment facilities are needed to be put up similar to the concessionaire engaged in this paper.

Several of the concessionaire's groundwater sources have presence of varying levels of dieldrin in parts per million (ppm). Some have levels which at times exceeds the allowable PNSDW limits. Concentrations typically range from half to more than 7 times that of PNSDW. Activated carbon was employed to eliminate water contamination in the area.

Meanwhile, Fe and Mn problem are only limited to a few wells. Routine test shows that Iron and Manganese is present only in small concentrations which marginally exceed the PNSDW. However, oxidation of these materials is creating color, turbidity, staining and odor issues in the water. DMI-65 (a powerful catalytic water filtration media designed for the removal of iron and manganese in water) was employed to capture the particulates present in wells.

To wit, Fe, Mn and Dieldrin are the main parameters that pose threat to the water concessionaire. The company have put up various treatment facilities (combination of individual treatment facilities constructed for each well and collective flow treatment facilities combining flow of several wells to a single plant) to bring down levels to PNSDW limits.

Tech innovation is already embedded into the company's DNA. The company's vision statement;

"We aspire to become a premier water and environmental services provider...'

has pushed them to continually improve and seek out better and innovative approaches that can be applied to its operations.

On May 2019, a vendor introduced a product claiming to effectively treat slime and other related parameters with zero operating expenses. During the initial meetup, vendor assured the concessionaire that their product can effectively remove Fe and $\mathrm{Mn}$. To prove its worth, the vendor provided the concessionaire demo to buy units. With those tempting favors, the concessionaire agreed to install units to two (2) of its worst affected wells. The following are the product claims as replicated from the vendor's website.

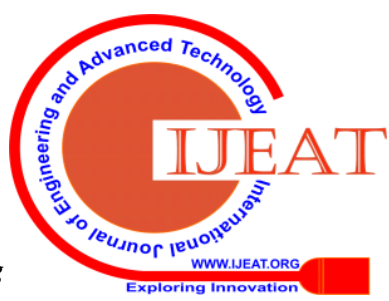


a) Removes rust, scale, slime and corrosion preventer

b) Ionic exchange

c) Self-operated

d) No maintenance

e) Extends the lifespan of water pipes and equipment

f) Bacteria and biofilm eliminator

g) Remove pathogens

h) Reduce level of materials which are harmful to health and

i) Reduce the level of rusting

\section{A. Statement of the Problem}

Though the concessionaires' existing treatment system has been effective throughout, it has been actively seeking out alternative treatment technologies. Among the new technologies that came up strong is the ionizing treatment apparatus due to its zero-operating expense. Firsthand data is needed to determine whether this technology can perform as claimed and whether it is capable to replace the concessionaire's somewhat costly system.

\section{B. Objectives}

The purpose of this paper attempts to evaluate the performance of the proposed ionizing treatment apparatus as opposed to its claims. More specifically, the paper will analyze its treatment efficiency for physicochemical and bacteriological parameters especially for Fe, Mn and dieldrin. $\mathrm{Fe}, \mathrm{Mn}$ and dieldrin were highlighted since they are the parameters that pose challenge to the water concessionaire.

The researcher aims:

- To perform sampling and tests for the physicochemical, bacteriological and organics parameters of the raw water quality entering and exiting the apparatus

- To tabulate results and compute for the apparatus' treatment efficiency

- To deliberate actual results and benchmark against the product claims.

\section{Significance}

The study will serve as aide for the concessionaire's management to better their judgement whether this venture is worth their time and resources. The paper may also serve as guide for fellow consultants and other concessionaires/water suppliers having similar issues with Fe, Mn and Dieldrin and are looking for alternative treatment options.

\section{Scope and Limitation}

This study is limited to the information provided (either visual or auditory) by the product supplier and their claims as posted in their website. The researcher is likewise limited to standard operating procedures i.e. installation and operation as specified by the supplier. Amongst the product claims, only letters a, b, $\mathrm{f}$ and $\mathrm{g}$ of the list above were examined due to the limited observation period. Letters $\mathrm{c}$ and d; self-operation and zero maintenance were adhered during the study. The apparatus was only provided free for 1 month use thus; testing was limited to the given timeframe.

\section{METHODOLOGY}

\section{A.Conceptual Framework}

The study made use of a simple input-process-output model as shown in Figure 1.

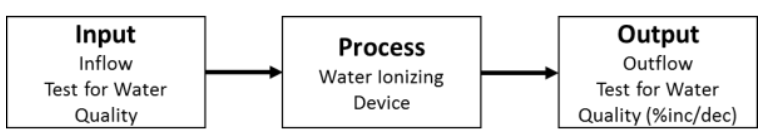

Figure 1: Input-Process-Output Approach

The product - a plug and play, standard 2-inch diameter, commercially available ionizing treatment apparatus using carbon nanotubes was installed in 2 wells. It was placed in the raw water sampling station right after the well's riser pipe and air release valve (ARV). Additional valves were installed to allow water sampling coming in and out of the apparatus. The whole activity was supervised by the product owners to ensure proper installation and operation.

Grab samples from the inflow were taken first followed by the outflow and recorded the time of sampling for both. Each set is comprised of device's inflow and outflow sample. Samples were then tested for the following parameters: Chlorides, Total Hardness, Calcium Hardness, Ca, Mg, pH, Turbidity, TDS, color, Fe, Mn, Total coliform, HPC count and Dieldrin. Collection, handling, storage and transport followed the standard methods ${ }^{[1]}$ for water analysis.

Inflow and Outflow sampling was done successively for 7 working days. 3 samples on a single day was also done during $3^{\text {rd }}$ day of sampling. Weekly sampling for 3 weeks commenced afterwards. The study period lasted approx. 28 days and a total of 39 samples were taken throughout the water quality monitoring. Testing were conducted by laboratories accredited by the Department of Health (DOH). Test results were tallied, and the inflow and outflow difference including its percentage for increase and/or decrease were computed to test the apparatus' efficacy. The formula used in determining the percentage removal efficiency is given as:

\%increase/decrease $=\frac{\text { outflow }- \text { Inflow }}{\text { Inflow }} x 100 \%$

\section{RESULTS AND DISCUSSIONS}

Sampling results for the Physico-Chemical parameters are shown in Table 1. Table 2 on the other hand presents the water device's removal efficiency of the said parameters. The products' claims were verified thru actual test results and are discussed in the following sections. 
Table 1: Physico-Chemical Results, Inflow And Outflow

\begin{tabular}{|c|c|c|c|c|c|c|c|c|c|c|c|c|c|}
\hline & Parameters & Temp. & $\mathrm{Cl}$ & $\begin{array}{c}\text { Total } \\
\text { Hardne } \\
\text { ss }\end{array}$ & $\begin{array}{c}\text { Calciu } \\
\text { m } \\
\text { Hardn } \\
\text { ess } \\
\end{array}$ & $\mathrm{Ca}$ & $\mathrm{Mg}$ & $\mathrm{pH}$ & $\begin{array}{c}\text { Turbidi } \\
\text { ty }\end{array}$ & TDS & Color & Iron & Mn \\
\hline & Method & & \multicolumn{3}{|c|}{ Titrimetric } & & & $\begin{array}{c}\text { Electr } \\
\text { ometri } \\
\text { c }\end{array}$ & $\begin{array}{l}\text { Nephel } \\
\text { ometric }\end{array}$ & $\begin{array}{l}\text { Condu } \\
\text { ctivity } \\
\text { Probe }\end{array}$ & $\begin{array}{c}\text { Visua } \\
1 \\
\text { comp } \\
\text { arison } \\
\end{array}$ & \multicolumn{2}{|c|}{ Colorimetric } \\
\hline & Unit & ${ }^{0} \mathrm{C}$ & $\begin{array}{c}\mathrm{mg} / \\
\mathrm{L}\end{array}$ & $\mathrm{mg} / \mathrm{L}$ & mg/ L & $\begin{array}{c}\mathrm{mg} / \\
\mathrm{L}\end{array}$ & $\begin{array}{c}\mathrm{mg} / \\
\mathrm{L}\end{array}$ & & NTU & $\mathrm{mg} / \mathrm{L}$ & PCU & $\mathrm{mg} / \mathrm{L}$ & $\mathrm{mg} / \mathrm{L}$ \\
\hline & PNSDW Limit & & 250 & 300 & - & - & - & $\begin{array}{c}6.5- \\
8.5 \\
\end{array}$ & 5 & 600 & 10 & 1 & 0.4 \\
\hline Source/Station ID & Date \& Time & & & & & & & & & & & & \\
\hline DW38 Inflow & 5/30/19 14:45 & 28.9 & 13 & 263 & 125 & 50 & 33 & 6.58 & 3.12 & 219 & 15 & 0.32 & 0.1 \\
\hline DW38 Outflow & 5/30/19 14:32 & 29.3 & 13 & 250 & 125 & 50 & 30 & 6.8 & 1.79 & 217 & 15 & 0.27 & 0.1 \\
\hline DW38 Inflow & 5/31/19 13:30 & 28.8 & 13 & 250 & 125 & 50 & 30 & 6.53 & 2.88 & 214 & 12.5 & 0.28 & 0.5 \\
\hline DW38 Outflow & 5/31/19 13:33 & 28.9 & 14 & 250 & 125 & 50 & 30 & 6.58 & 2.34 & 218 & 17.5 & 0.63 & 0.6 \\
\hline DW38 Inflow & 6/3/19 12:33 & - & 12 & 250 & 125 & 50 & 30 & 6.65 & 2.97 & 221 & 20 & 0.52 & 0.1 \\
\hline DW38 Outflow & 6/3/19 12:30 & - & 13 & 250 & 125 & 50 & 30 & 6.69 & 2.63 & 221 & 20 & 0.49 & 0.1 \\
\hline DW38 Inflow & 6/3/19 12:15 & - & 10 & 250 & 125 & 50 & 30 & 6.62 & 3.21 & 218 & 17.5 & 0.51 & 0.1 \\
\hline DW38 Outflow & 6/3/19 12:18 & - & 13 & 263 & 138 & 55 & 30 & 6.68 & 2.67 & 215 & 15 & 0.53 & 0.1 \\
\hline DW38 Inflow & 6/3/19 10:12 & - & 12 & 300 & 150 & 60 & 36 & 6.65 & 1.41 & 220 & 15 & 0.53 & 0.1 \\
\hline DW38 Outflow & 6/3/19 10:15 & - & 13 & 300 & 150 & 60 & 36 & 6.74 & 1.62 & 220 & 15 & 0.54 & 0.1 \\
\hline DW38 Inflow & 6/4/19 11:12 & 28.9 & 16 & 263 & 145 & 58 & 29 & 6.79 & 3.64 & 224 & 20 & 0.65 & 0.1 \\
\hline DW38 Outflow & 6/4/19 11:15 & 28.8 & 8 & 263 & 138 & 55 & 30 & 6.88 & 4.1 & 225 & 20 & 0.64 & 0.1 \\
\hline DW38 Inflow & 6/5/19 12:48 & 29.5 & 13 & 268 & 138 & 55 & 32 & 6.74 & 4.22 & 225 & 25 & 0.57 & 0.2 \\
\hline DW38 Outflow & 6/5/19 12:42 & 29.4 & 16 & 250 & 125 & 50 & 30 & 6.79 & 3.75 & 224 & 17.5 & 0.55 & 0.1 \\
\hline DW38 Inflow & 6/6/19 14:45 & 29.1 & 8 & 263 & 150 & 60 & 27 & 6.72 & 11.9 & 221 & 35 & 1.3 & 0.1 \\
\hline DW38 Outflow & 6/6/19 14:50 & 29.2 & 8 & 275 & 150 & 60 & 30 & 6.96 & 23.4 & 228 & 70 & 2.19 & 0.1 \\
\hline DW38 Inflow & 6/11/19 10:55 & 29.6 & 13 & 263 & 138 & 55 & 30 & 6.87 & 1.16 & 225 & 15 & 0.63 & 0.1 \\
\hline DW38 Outflow & 6/11/19 10:58 & 29.7 & 13 & 263 & 138 & 55 & 30 & 6.93 & 2.57 & 227 & 17.5 & 0.68 & 0.1 \\
\hline DW6 Inflow & 6/25/19 11:38 & 28.7 & 13 & 250 & 125 & 50 & 30 & 6.6 & 0.06 & 209 & 5 & 0.02 & 0.1 \\
\hline DW6 Outflow & 6/25/19 11:42 & 28.7 & 13 & 250 & 125 & 50 & 30 & 6.5 & 0.06 & 210 & 10 & 0.02 & 0.1 \\
\hline DW6 Inflow & 6/27/19 10:57 & 28.6 & 13 & 250 & 125 & 50 & 30 & 6.5 & 0.06 & 210 & 2.5 & - & 0.1 \\
\hline DW6 Outflow & 6/27/19 11:03 & 28.6 & 13 & 263 & 130 & 52 & 32 & 6.51 & 0.12 & 210 & 2.5 & 0.04 & 0.1 \\
\hline
\end{tabular}

Table 2: Removal Efficiency of Physico - Chemical Parameters

\begin{tabular}{|c|c|c|c|c|c|c|c|c|c|c|c|c|}
\hline $\begin{array}{c}\text { Source/ } \\
\text { Station ID }\end{array}$ & Temp. & Cl & $\begin{array}{c}\text { Total } \\
\text { Hardness }\end{array}$ & $\begin{array}{c}\text { Calcium } \\
\text { Hardness }\end{array}$ & Ca & Mg & pH & Turbidity & TDS & Color & Iron & Mn \\
\hline DW38 Day1 & $1.38 \%$ & $0.00 \%$ & $-4.94 \%$ & $0.00 \%$ & $0.00 \%$ & $-9.09 \%$ & $3.34 \%$ & $-42.63 \%$ & $-0.91 \%$ & $0.00 \%$ & $-15.63 \%$ & $0.00 \%$ \\
\hline DW38 Day2 & $0.35 \%$ & $7.69 \%$ & $0.00 \%$ & $0.00 \%$ & $0.00 \%$ & $0.00 \%$ & $0.77 \%$ & $-18.75 \%$ & $1.87 \%$ & $40.00 \%$ & $125.00 \%$ & $20.00 \%$ \\
\hline DW38 Day3.1 & - & $8.33 \%$ & $0.00 \%$ & $0.00 \%$ & $0.00 \%$ & $0.00 \%$ & $0.60 \%$ & $-11.45 \%$ & $0.00 \%$ & $0.00 \%$ & $-5.77 \%$ & $0.00 \%$ \\
\hline DW38 Day3.2 & - & $30.00 \%$ & $5.20 \%$ & $10.40 \%$ & $10.00 \%$ & $0.00 \%$ & $0.91 \%$ & $-16.82 \%$ & $-1.38 \%$ & $-14.29 \%$ & $3.92 \%$ & $0.00 \%$ \\
\hline DW38 Day3.3 & - & $8.33 \%$ & $0.00 \%$ & $0.00 \%$ & $0.00 \%$ & $0.00 \%$ & $1.35 \%$ & $14.89 \%$ & $0.00 \%$ & $0.00 \%$ & $1.89 \%$ & $0.00 \%$ \\
\hline DW38 Day4 & $-0.35 \%$ & $-50.00 \%$ & $0.00 \%$ & $-4.83 \%$ & $-5.17 \%$ & $3.45 \%$ & $1.33 \%$ & $12.64 \%$ & $0.45 \%$ & $0.00 \%$ & $-1.54 \%$ & $0.00 \%$ \\
\hline DW38 Day5 & $-0.34 \%$ & $23.08 \%$ & $-6.72 \%$ & $-9.42 \%$ & $-9.09 \%$ & $-6.25 \%$ & $0.74 \%$ & $-11.14 \%$ & $-0.44 \%$ & $-30.00 \%$ & $-3.51 \%$ & $-50.00 \%$ \\
\hline DW38 Day6 & $0.34 \%$ & $0.00 \%$ & $4.36 \%$ & $0.00 \%$ & $0.00 \%$ & $10.00 \%$ & $3.45 \%$ & $49.15 \%$ & $3.07 \%$ & $50.00 \%$ & $40.64 \%$ & $0.00 \%$ \\
\hline DW38 Week2 & $0.34 \%$ & $0.00 \%$ & $0.00 \%$ & $0.00 \%$ & $0.00 \%$ & $0.00 \%$ & $0.87 \%$ & $121.55 \%$ & $0.89 \%$ & $16.67 \%$ & $7.94 \%$ & $0.00 \%$ \\
\hline DW6 Week1 & $0.00 \%$ & $0.00 \%$ & $0.00 \%$ & $0.00 \%$ & $0.00 \%$ & $0.00 \%$ & $-1.52 \%$ & $0.00 \%$ & $0.48 \%$ & $100.00 \%$ & $0.00 \%$ & $0.00 \%$ \\
\hline DW6 Week2 & $0.00 \%$ & $0.00 \%$ & $5.20 \%$ & $4.00 \%$ & $4.00 \%$ & $6.67 \%$ & $0.15 \%$ & $100.00 \%$ & $0.00 \%$ & $0.00 \%$ & \#DIV/0! & $0.00 \%$ \\
\hline
\end{tabular}

Scale prevention can be related to hardness, Fe and Mn removal. Bacteria and pathogen removal can be verified thru Total Coliform testing and HPC count. Self-operated and zero maintenance requirements were observed firsthand. Meanwhile, extension of lifespan of pipes and equipment and reduction of rusting were waived in the discussion due to time constraints with the actual product.

\section{A.Hardness and Scale Formation}

Total hardness is caused by dissolved minerals, primarily divalent cations. In natural water systems, calcium and magnesium are the main contributing ions for total hardness [3].

Published By: 
Total hardness increased by an average of $0.28 \%$ while calcium hardness was reduced by a mere $0.01 \%$. Ca content also decreased by $0.02 \%$ contrary, $\mathrm{Mg}$ increased by $0.43 \%$. $\mathrm{Ca}$ and $\mathrm{Mg}$ were highlighted for the claims on Ionic exchange, which shows that the technology could not work as water softener, as evidenced by no variation of Total Hardness from feed and product water.

Another salient thing to note with regards to hardness is that when water becomes "hard" it can have its toll on pipes [4] due to formation of scale - a red flag as the product promises scale removal.

\section{B. Turbidity, TDS and Color}

Turbidity is a common indicator for the general condition of the drinking water. Similarly, color affects aesthetics and detracts the appearance of water. Dissolved solids on the other hand refer to minerals and some small amounts of organic matter that are dissolved in water [2].

Turbidity, TDS and color themselves are not major health concerns, but high levels can interfere with disinfection and provide a medium for microbial growth. All (18) raw water samples that came from the 1st station have failed the PNSDW standards for color and two (2) samples failed turbidity. The 2nd station did not have problems similar of the first. Treatment is not working as it should since turbidity levels increased by an average of $17.95 \%$, TDS by $0.37 \%$ and color by $14.76 \%$.

\section{C.Iron and Manganese}

Fluctuating amounts of $\mathrm{Fe}$ and $\mathrm{Mn}$ manifested in both sampling stations. On the flip side, dieldrin is a problem unique for the 2nd station. Results of these problem parameters are as follows: Fe increased by $15.29 \%$ however, managed to bring down Mn by $2.73 \%$. The decrease can be exclusively attributed to a single sample wherein Mn was initially recorded at 0.2 and went down to $0.1 \mathrm{mg} / \mathrm{L}$. All other samples either have $0 \%$ removal whereas 1 batch increased Mn by $20 \%$.

Shown in Table 3 are the Microbiological parameters while Table 4 presents the device's removal efficiency.

Table 3: Microbiological Results, Inflow and Outflow

\begin{tabular}{|c|c|c|c|c|c|}
\hline & Parameters & Total Coliform & $\begin{array}{l}\text { Thermotolerant } \\
\text { Coliform/E.coli }\end{array}$ & $\begin{array}{c}\text { Heterotrophic } \\
\text { Plate Count }\end{array}$ & $\begin{array}{l}\text { Residual } \\
\text { Chlorine }\end{array}$ \\
\hline & Method & \multicolumn{2}{|c|}{ MTFT/EST } & Pour Plate & Colorimetric \\
\hline & Unit & \multicolumn{2}{|c|}{$M P N / 100 \mathrm{~mL}$} & $C F U / m L$ & $m g / L$ \\
\hline \multicolumn{2}{|c|}{ PNSDW Limit } & \multicolumn{2}{|c|}{$<1.1 /<1$, Absent } & $<500$ & $0.30-1.50$ \\
\hline Location & Date \& Time & & & & \\
\hline DW38 Inflow & 5/30/19 14:45 & 1 & 1 & \multirow{3}{*}{$\begin{array}{l}\text { COLILERT } \\
\text { QuantiTray }\end{array}$} & 0.02 \\
\hline DW38 Outflow & 5/30/19 14:32 & 1 & 1 & & 0.02 \\
\hline DW38 Outflow & 5/30/19 14:35 & 1 & 1 & & 2.2 \\
\hline DW38 Inflow & 5/31/19 13:30 & Absent & Absent & 30 & 0.02 \\
\hline DW38 Outflow & 5/31/19 13:33 & Absent & Absent & 630 & 0.01 \\
\hline DW38 Inflow & $6 / 3 / 19$ 10:12 & Absent & Absent & 86 & 0.01 \\
\hline DW38 Outflow & $6 / 3 / 19$ 10:15 & Absent & Absent & 1250 & 0.01 \\
\hline DW38 Inflow & 6/5/19 12:48 & Absent & Absent & 90 & 0 \\
\hline DW38 Outflow & 6/5/19 12:42 & Absent & Absent & 520 & 0 \\
\hline DW38 Inflow & $6 / 11 / 1910: 55$ & Absent & Absent & 110 & - \\
\hline DW38 Outflow & $6 / 11 / 1910: 58$ & Absent & Absent & 1220 & - \\
\hline DW6 Inflow & $6 / 24 / 1911: 38$ & 2 & 1 & \multirow{4}{*}{$\begin{array}{l}\text { COLILERT } \\
\text { QuantiTray }\end{array}$} & - \\
\hline DW6 Outflow & $6 / 24 / 1911: 42$ & 1 & 1 & & - \\
\hline DW6 Inflow & $6 / 27 / 1910: 57$ & 13.7 & 1 & & - \\
\hline DW6 Outflow & 6/27/19 11:03 & 4.2 & 1 & & - \\
\hline
\end{tabular}


Table 4: Removal Efficiency of Microbiological Parameters

\begin{tabular}{|l|c|c|c|}
\hline \multicolumn{1}{|c|}{ Parameters } & $\begin{array}{c}\text { Total } \\
\text { Coliform }\end{array}$ & $\begin{array}{c}\text { Thermotolerant } \\
\text { Coliform/E.coli }\end{array}$ & $\begin{array}{c}\text { Heterotrophic } \\
\text { Plate Count }\end{array}$ \\
\hline Source/Station ID & & & - \\
\hline DW38 Day1 & $0.0 \%$ & $0.0 \%$ & - \\
\hline DW38 Day2 & - & - & $2,000 \%$ \\
\hline DW38 Day3 & - & - & $1,353 \%$ \\
\hline DW38 Day4 & - & - & $478 \%$ \\
\hline DW38 Week2 & - & - & $1,009 \%$ \\
\hline DW6 Week1 & $-50.0 \%$ & $0.0 \%$ & - \\
\hline DW6 Week2 & $-69.3 \%$ & $0.0 \%$ & - \\
\hline
\end{tabular}

\section{D.Pathogens, HPC and Total Coliforms}

Raw water coming from the $1^{\text {st }}$ station readily comply with the PNSDW whereas the $2^{\text {nd }}$ station's raw water tested positive for coliforms; 2MPN/100mL during week 1 and 13.7MPN/100mL at week 2 .

The apparatus managed the removal of coliforms by an average of $59.67 \%$ but still failed to meet the PNSDW limit of either absent or $<1 \mathrm{MPN} / 100 \mathrm{~mL}$. Significant spikes in HPC are also notable (1,210\% average increase).

Sudden HPC increase signals a change in the quality of raw water or that bacterial regrowth has occurred in the system. As advertised, product did claim reduction but not elimination.

Table 5 show the values obtained for Dieldrin and its corresponding removal efficiency.

Table 5: Dieldrin and Removal Efficiency

\begin{tabular}{|l|c|c|}
\hline \multicolumn{1}{|c|}{ Station Identification } & $\begin{array}{c}\text { Dieldrin, }<\mathbf{0 . 0 3} \\
\mathbf{p p b} \text { limit }\end{array}$ & \% removal \\
\hline DW6 Inflow & 0.23 & \multirow{2}{*}{$21.7 \%$} \\
\hline DW6 Outflow & 0.28 & \\
\hline
\end{tabular}

\section{E. Dieldrin}

Despite not claiming organics removal, the researcher still tested the product for tis dieldrin removal capability. This has been a futile since the single batch sampled returned with an increase of $21.7 \%$ for dieldrin.

\section{CONCLUSIONS AND RECOMMENDATIONS}

4 of the 9 product claims were assessed and the series of tests conducted was already conclusive that the water ionizing device cannot be used for the treatment of concessionaire's water quality. The product failed in the treatment of Hardness, Ca, Mg, TDS, color, and Fe. The product initially managed to bring down Turbidity levels by as much as $42.63 \%$ but the results were not consistent. Succeeding tests increased Turbidity by $100 \%$ and $121.55 \%$. The product also managed to bring down Mn levels by $50 \%$ but was only a one-time event, therefore not consistent with its claims. The product also fell short of the PNSDW for pathogens present in water. Another futile attempt was the test for dieldrin removal. Overall, the results show non-favorable treatment capacity of the product hence not recommended to be used by the company.

Meanwhile, the technology provider should consider a thorough study for different length or size of the system to anticipate reaction time and maintenance of the treatment device. Treatment is always dependent on water source quality. The device may be applicable after undergoing treatment process from water utility industries but not for raw

ground water sources, specifically with the concessionaire involved in this study. In dealing with new devices that have several claims in the treatment of water, it is customary for others to be overwhelmed by the promises of these products and can easily be drawn into purchasing them outright. The result of the study have shown otherwise that not all claims of product being endorsed are fully reliable. Most parameters shown in product catalogues need verification by product performance qualification.

\section{REFERENCES}

1. American Public Health Association, American Water Works Association, Water Environment Foundation (2017) Standard Methods of examination of Water and Wastewater, 23rd edition.

2. Oram B. (n.d.) Water Research Center. Water Testing Total Dissolved Solids Drinking Water Quality Retrieved October 11, 2019 from https://www.water-research.net/index.php/water-treatment/tools/total-d issolved-solids

3. Puretec (n.d.) Basics of water softening. Retrieved October 27, 2019 from

https://puretecwater.com/downloads/basics-of-water-softening-by-ion-e xchange.pdf

4. Salam et.al. (2011, Nov 14) Corrosion and Scale Formation Problems in Water Systems. Retrieved October 27, 2019 from https:/www.researchgate.net/publication/278486524_Corrosion_and_S cale_Formation_Problems_in_Water_Systems

\section{AUTHORS PROFILE}

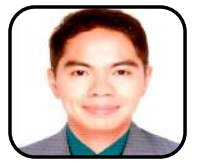

Manalang Mark Franklin P. a Registered Master Plumber and a Registered Mechanical Engineer. Mark is the Operations Manager for Clark Water Corporation (CWC). Mark also teach for the Mechanical Engineering Department of Holy Angel University where he handles fluid mechanics, fluid machineries, engineering ethics, and logistics management. He is also a freelance - with a Research \& Design background, focused on Environmental Impact Assessment preparation and wastewater design for individual clients up to municipal levels treatment plants. He finished both degrees for BS Mechanical Engineering and Master's in Engineering Management at Holy Angel University. He is currently pursuing his doctorate degree in Engineering Management in Nueva Ecija University of Science and Technology (NEUST).

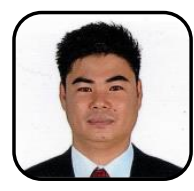

Infante Wilfredo L. is a Licensed Mechanical Engineer. $\mathrm{He}$ is currently the Program Chairperson of the Mechanical Engineering Department of Holy Ange University. He had worked in several manufacturing industries specialized in production of raw materials for semiconductor and processing of raw materials for automobiles. He finished his degree in Master of Science in Engineering Management in the same school. He is currently pursuing his degree in Doctor of Philosophy in Engineering Management at Nueva Ecija University of Science and Technology. His research interest ranges from design and development of machines for the improvement of small-scale industries, tracer studies of graduates, energy management system and design of mechanical system and its performance. He is co-researcher for government funded researches awarded to Holy Angel University. He is one of the makers of the first patent of Holy Angel University under the Utility Model Registration with the title Foam Shredding Machine.

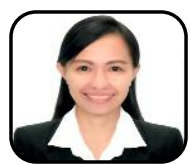

Alonto Al-Shaimah A. A Registered Chemist. She finished her Bachelor of Science in Chemistry in Mindanao State University (MSU)-Main Campus, Marawi City. Her undergraduate thesis is titled: Pesticide Residue Analysis on the Two Major Tributaries of Lake Lanao. She is also the adviser of MSU - Student's League for Academic Advancement and Progress (SLAAP) and a member of the Integrated Chemist of The Philippines (since 2006). She is the current Laboratory Services Manager of Clark Water Corporation (CWC). 


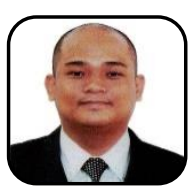

De Lara Ryan John L. A Licensed Electronics Engineer, Accredited Broadcaster, Certified Cable Test Technician and Six Sigma Black Belt Certified. He is currently the Director for Research Development and Productivity Office and the former Dean of the College of Engineering and Computer Technology of Wesleyan University - Philippines Cushman Campus. He finished both his Masters and Doctor of Philosophy in Engineering Management at Nueva Ecija University of Science and Technology. The interim governor of the Institute of Electronics Engineers of the Philippines - Nueva Ecija Chapter (Accreditation No. 37). His research interest ranges from electronics system design, microcontroller application, energy system optimization, prototype development and electronics waste (e-waste) management.

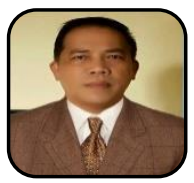

Florencondia Noel T. A Professional Electrical Engineer and Dean of the College of Engineering of Nueva Ecija University of Science and Technology (NEUST). A Professional Electrical Engineer (PEE) and Graduate of Doctor of Philosophy in Engineering Management (PhD. EnM) at Nueva Ecija University of Science and Technology (NEUST). A member of Institute on Integrated Electrical Engineers. Electrical System Design, High Rise Building Designs and Arc Flashes are his field of research. 